\title{
THE IMPACT OF TRADE IN GDP PER CAPITA GROWTH IN 2018
}

\author{
Ionela-Cătălina ZAMFIR \\ Bucharest University of Economic Studies, Romania \\ ionela.zamfir@csie.ase.ro
}

\begin{abstract}
Nowadays, the dynamic of world economies and the economic relationships between countries have a high influence on economic growth. It is possible to say that the international trade impact in GDP is, for most economies, the main criteria for economic growth. Due to natural resources endowments, each country has its own specificity. There are many studies regarding the impact of exports and imports in GDP using time-series and econometrics methods. This study uses a combined methodology between data analysis and econometrics (principal components regression) in order to identify the impact that trade has on GDP per capita growth, taking into account the majority of world economies from 2018. The use of principal components analysis reduces very much the dimensionality of data (from 22 variables to 4 principal components) and helps with the multicollinearity problem, while linear regression is used to estimate the impact of trade in GDP per capita growth. The results of applying PCR method on all considered countries show a moderately influence of trade in GDP per capita growth that should not be overlooked when it comes to identify the main factors that influence the gross domestic product growth.
\end{abstract}

Keywords: principal components regression, trade, GDP per capita growth, multicollinearity JEL classification: $\mathrm{C} 38, \mathrm{~F} 1$

DOI: $10.24818 / \mathrm{ie} 2020.05 .04$

\section{Introduction and literature review}

The level of natural resources endowments is essential for trade is an open economy. The resources are very important for trade. The impact of trade in GDP or economic growth is a subject of interest nowadays. Researchers from around the world analyze the long-term relation between different components of trade and the impact in economic growth. Many studies describe the relationship between trade and GDP or economic growth using time-series approach and econometrics methods. A different approach could represent the use of principal components regression taking into consideration the most relevant economies in the world.

In a study from 2014 (Mogoe, Mongale, 2014 - [1]), authors use econometric approach to identify the impact that trade has on economic growth in South Africa. They identify a positive relation between GDP and exchange rates, inflation rate and export and a negative relation between GDP and import using methods like VECM (vector error correction model) and quarterly data from 1990Q1 to 2013Q2. In 2017 (Keho, 2017 - [2]) a study reveals the impact of trade on economic growth for Cote d'Ivoire using data from 1965 to 2014 and econometric methods. Author identifies "the existence of a long-run relationship between economic growth, capital stock, labor, and trade openness" (Keho, 2017 - [2]).

In 2010, another study (Sun, Heshmati, 2010 - [3]) considers 31 provinces from China for 2002-2007 period as data, and econometric methods to show that the dynamic trade in China led to high economic growth. For Canada (Bakari, 2016 - [4]), the data used is between 1990 and 2015 and methods like VAR (vector auto regression) and Granger causality tests show the relation between the economic growth and variables like exports and imports. For 6 countries from European Union (Michelis, Zestos, 2004 - [5]), VECM was used on time-series data to 
demonstrate the relations between exports, imports and GDP (real data series). Their findings were that export and import have a strong influence on GDP in almost all analyzed countries (Belgium, France, Germany, Greece, Italy and Netherlands). On the other side, in Czech and Slovak Republics, the relation between trade and economic growth was analyzed (Fitzová, Žídek, 2015 - [6]) using econometric analysis (like VAR, VEC, cointegration) and quarterly data from 1997Q1 (for Slovak Republic) or 1996Q1 (for Czech Republic) until 2014Q4 (both countries). The results show that international trade "was probably a crucial factor of the economic growth" (Fitzová, Žídek, 2015 - [6]). In the same year, another author (Were, 2015 - [7]) performed a similar analysis of the effect of trade on economic growth, considering more countries, grouped by the development level (developed, developing and least developed countries) and using regression as methodology. The results of the study (Were, 2015 - [7]) reveal a positive relationship between economic growth and trade.

In a recent study (Huchet, Le Mouel, Vijil, 2018 - [8]), the relation between trade and economic growth is analyzed by taking into consideration 169 countries and data between 1988 and 2014 . Authors used an estimator based on generalized method of moments and their results "confirm that countries exporting higher quality products and new varieties grow more rapidly"[8].

After the literature review, the methodologies, variables and dataset considered are presented, then the application main results, followed by the main conclusions, limitations for the study and further research.

\section{Methodologies, variables and dataset}

The main methodology used here is $\mathrm{PCR}^{1}$ (principal components regression) that is a combination between data analysis methods and econometric models. PCR suppose performing regression on principal components, used as independent variables. The main advantage of PCR is that the multicollinearity problem for a multifactorial regression model is solved, because the principal components are not correlated one with each other.

The variables considered for this model refer to trade, import and export indicators, as well as GDP indicators (like GDP per capita, GDP growth and GDP per capita growth). From the entire world countries, 123 countries (with available data, few missing data were replaced by variable's mean) were selected and 22 export, import and trade variables, plus GDP indicators for 2018, the main source of data being the World Bank website ${ }^{2}$. The variables are: $\mathrm{X}_{1}=$ commercial service exports (current US\$), $\mathrm{X}_{2}=$ commercial service imports (current US\$), $\mathrm{X}_{3}=$ cost to export, border compliance (US\$), $\mathrm{X}_{4}=$ cost to import, border compliance (US\$), $\mathrm{X}_{5}=$ export value index $(2000=100), \mathrm{X}_{6}=$ goods exports (current US $\left.\$\right), \mathrm{X}_{7}=$ goods imports (current US\$), $\mathrm{X}_{8}=$ international tourism, receipts for travel items (current US\$), $\mathrm{X}_{9}=$ ability to track and trace consignments ( $1=$ low to $5=$ high), $X_{10}=$ competence and quality of logistics services $(1=$ low to $5=$ high $), X_{11}=$ ease of arranging competitively priced shipments (1=low to $5=$ high), $X_{12}=$ efficiency of customs clearance process (1=low to $5=$ high), $X_{13}=$ frequency with which shipments reach consignee within scheduled or expected time (1=low to $5=$ high), $\mathrm{X}_{14}=$ overall (1=low to $5=$ high), $\mathrm{X}_{15}=$ quality of trade and transport-related infrastructure (1=low to $5=$ high), $X_{16}=$ merchandise exports (current US\$), $X_{17}=$ merchandise imports (current US\$), $\mathrm{X}_{18}=$ merchandise trade (\% of GDP), $\mathrm{X}_{19}=$ service exports (current US $\$$ ), $\mathrm{X}_{20}=$ service imports (current US\$), $\mathrm{X}_{21}=$ time to export, border compliance (hours), $\mathrm{X}_{22}=$ time to import, border compliance (hours).

\footnotetext{
${ }^{1}$ https://en.wikipedia.org/wiki/Principal_component_regression

${ }^{2}$ https://data.worldbank.org/indicator
} 


\section{Application main results}

In order to apply PCR methodology on selected dataset, descriptive statistics applied on variables are essential to present an overview of indicators.

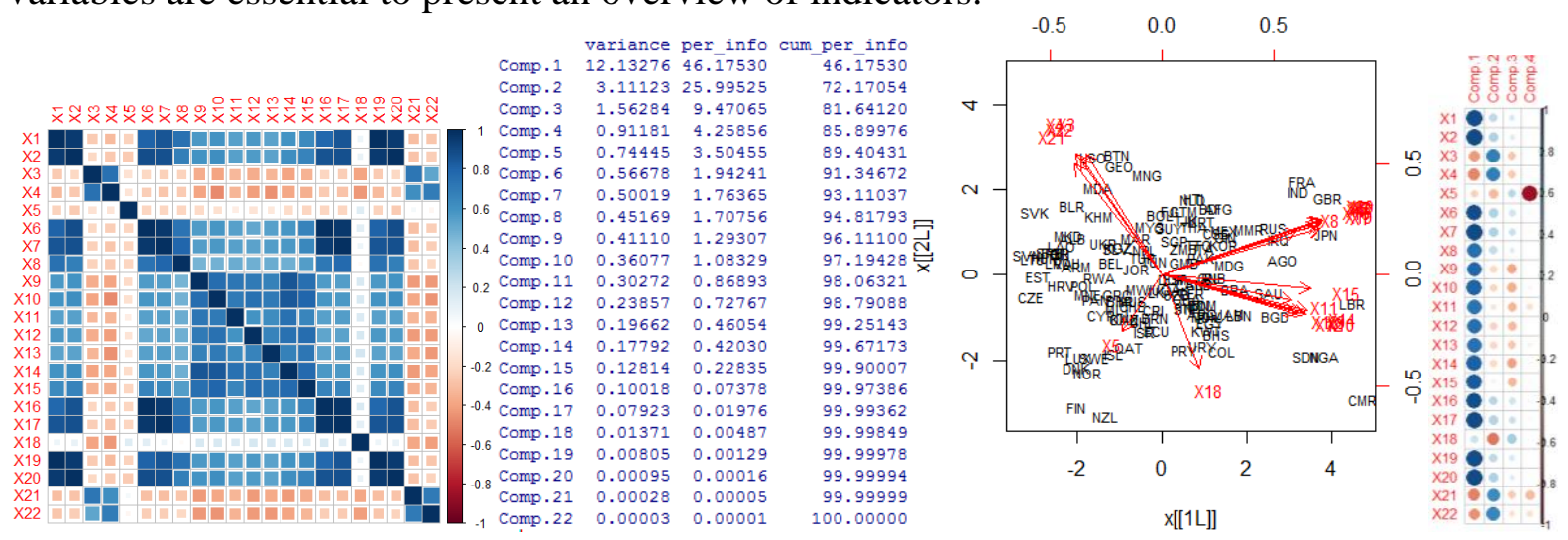

Source: author's computations

Figure 1. Correlation matrix of variables and PCA results

The correlation matrix and PCA results ${ }^{3}$ are presented above (Figure 1 from above describe $\mathrm{R}$ outputs). The high correlations between original variables as well as the high number of variables confirm the use of principal components analysis in order to compute new aggregated variables. Considering four principal components (although, according to Kaiser criteria, only 3 eigenvalues are higher than unit, the fourth eigenvalue is 0.91 , close to the unit), the amount of information synthesized is almost $86 \%$ from total information of all 22 original variables. The biplot figure shows the graphically representation of countries in principal plan. Countries with high value for $\mathrm{W}_{1}$ have a high development level from trade point of view (including here the logistics of trade), while countries with low values for $\mathrm{W}_{1}$ have a "weaker" trade system, comparing to other countries.

The correlation matrix between the original variables and principal components (the right figure from above) indicates that the first principal component is highly correlated with variables that show the import and export (commercial, goods, services or merchandise) and with variables that indicate the logistics of trade and can be named as $\mathrm{W}_{1}=$ import and export amount and logistics, while the second principal component is strongly correlated with variables that indicate the time of export/import, cost to import/export or merchandise trade (negative correlation). The second principal component can be named $\mathrm{W}_{2}=$ time, cost and merchandise trade component. The third principal component is correlated (weaker than the first principal component) with almost all variables, while the fourth principal component is very corelated with $\mathrm{X}_{5}=$ export value index.

Table 1. Multiple regression main results

Dependent Variable: GDP_CAP_GR_STD

Method: Least Squares

Sample: 1123

Included observations: 123

\begin{tabular}{crrrr}
\hline \hline Variable & Coefficient & Std. Error & t-Statistic & Prob. \\
\hline \hline C & $5.19 \mathrm{E}-08$ & 0.078402 & $6.62 \mathrm{E}-07$ & 1.0000 \\
W1 & 0.019995 & 0.022509 & 0.888340 & 0.3762 \\
W2 & -0.221042 & 0.044449 & -4.972931 & 0.0000 \\
W3 & 0.185832 & 0.062715 & 2.963122 & 0.0037
\end{tabular}

\footnotetext{
${ }^{3}$ The variables were standardized, due to different measurement units
} 
Proceedings of the IE 2020 International Conference

www.conferenceie.ase.ro

\begin{tabular}{lrlll}
\multicolumn{1}{c}{ W4 } & -0.247156 & 0.082106 & -3.010204 & 0.0032 \\
\hline \hline R-squared & 0.268719 & Mean dependent var & $5.69 \mathrm{E}-08$ \\
Adjusted R-squared & 0.243929 & S.D. dependent var & 1.000000 \\
S.E. of regression & 0.869523 & Akaike info criterion & 2.598058 \\
Sum squared resid & 89.21632 & Schwarz criterion & 2.712374 \\
Log likelihood & -154.7805 & Hannan-Quinn criter. & 2.644493 \\
F-statistic & 10.84015 & Durbin-Watson stat & 2.025784 \\
Prob(F-statistic) & 0.000000 & & \\
\hline
\end{tabular}

Source: author's computation

The table from above (Table 1) represents the main results of one ${ }^{4}$ econometric model, where GDP_CAP_GR_STD (GDP per capita growth - standardized series) is the dependent variable and principal components $\mathrm{W}_{1}$ to $\mathrm{W}_{4}$ are the independent variables. There are 123 countries. The R squared value is only 0.26 , therefore the impact of trade components in GDP per capita growth is not very high, but is also not insignificantly. The model is valid, taking into account the F-test (the probability associated to F-statistic is lower than 0.05 ), and most parameters are significantly different than 0 (the associated $\mathrm{p}$-value for t-tests are less than 0.05 ), except intercept and $\beta_{1}$ (the parameter for $\mathrm{W}_{1}$ ).

But, in order to validate the estimated model, it is necessary that all hypotheses of the multiple regression model to be fulfilled.

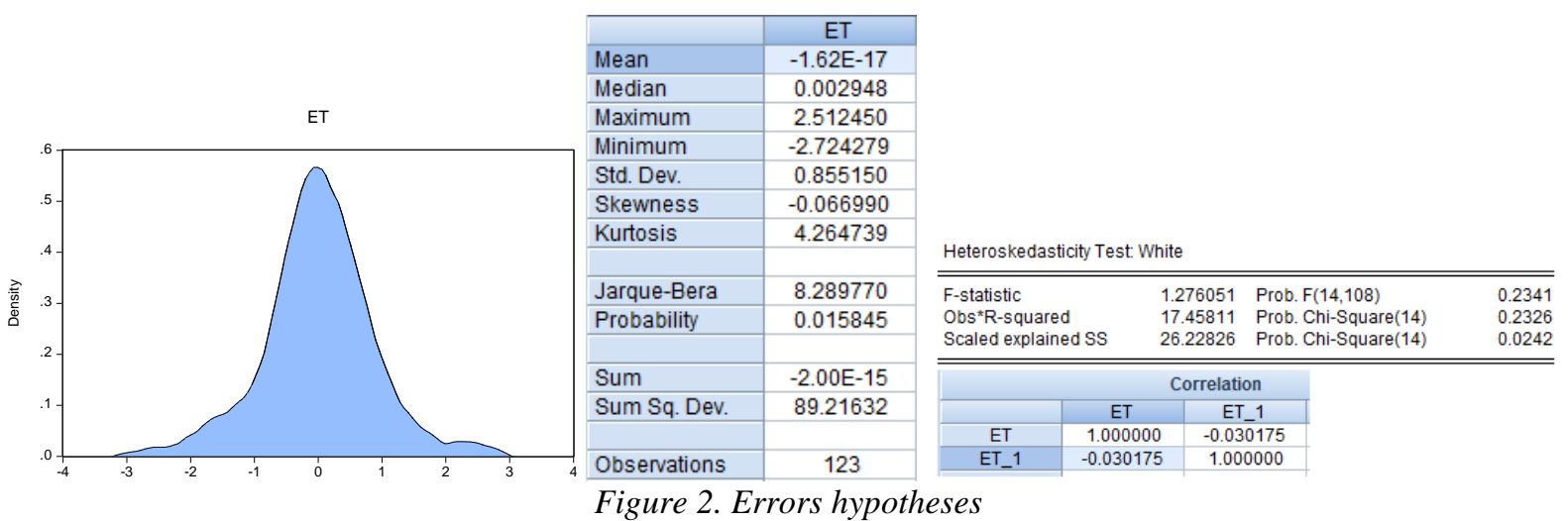

Source: author's computations

The figures from above (Figure 2) show that the residuals computed using the estimation from the above table are normally distributed, with zero mean. The output for White test (the right figure from above) have the associated p-value equal to $0.23>0.05$, so the null hypothesis is accepted, that states the homoskedasticity of errors.

On the other side, the autocorrelation of random errors is another hypothesis that should be considered in this case. The Durbin-Watson statistic is 2.02, in the third region of D-W test, so that the random errors are independent. The correlation between series et (estimated errors) and series et_1 show the non-autocorrelation of errors (the figure from above).

\footnotetext{
${ }^{4}$ Several models were performed, but only one with the best results is detailed
} 


\begin{tabular}{|c|c|c|c|c|c|}
\hline \multicolumn{6}{|c|}{ Correlation } \\
\hline & ET & W1 & W2 & W3 & W4 \\
\hline ET & 1.000000 & $4.87 \mathrm{E}-18$ & $-1.38 \mathrm{E}-17$ & $1.08 \mathrm{E}-16$ & $7.55 \mathrm{E}-17$ \\
\hline W1 & $4.87 \mathrm{E}-18$ & 1.000000 & $-1.46 \mathrm{E}-08$ & $-2.13 \mathrm{E}-09$ & $-7.22 \mathrm{E}-09$ \\
\hline W2 & $-1.38 \mathrm{E}-17$ & $-1.46 \mathrm{E}-08$ & 1.000000 & $2.63 \mathrm{E}-08$ & $2.01 \mathrm{E}-08$ \\
\hline W3 & $1.08 \mathrm{E}-16$ & $-2.13 \mathrm{E}-09$ & $2.63 \mathrm{E}-08$ & 1.000000 & $-2.56 \mathrm{E}-08$ \\
\hline W4 & $7.55 \mathrm{E}-17$ & $-7.22 \mathrm{E}-09$ & $2.01 \mathrm{E}-08$ & $-2.56 \mathrm{E}-08$ & 1.000000 \\
\hline
\end{tabular}

Source: author's computations

Figure 3. Multicolinearity hypothesis

Other hypotheses for the regression model (Figure 3 from above) state that: the covariance between estimated errors and regressors must be null and, the correlation between independent variables should be insignificant (the lack of multicollinearity). For principal components regression, the independent variables are principal components, that are computed in a way that assures the zero correlation between principal components: in the first principal component is considered the maximum information from the original variables, while the second principal component covers the maximum of information that is not included in the first principal component. This principle assures the zero correlation between principal components and solve the multicollinearity problem for PCR model (so the analysis of variance inflationary factor for multicollinearity is no longer required).

\section{Conclusions, discussions and further research}

The impact of trade in GDP is analyzed considering the GDP per capita growth indicator and other 22 variables that refer to import, export and trade. Although the $\mathrm{R}$ squared indicator show that about $26 \%$ of GDP per capita growth variance is explained in average by the first 4 principal components that synthesized about $86 \%$ of information from 22 variables, the quality of representation is significant.

The PCR method was used to estimate the regression coefficients of principal components. In order to estimate the coefficients for original variables, a transformation from principal components to original variables is possible considering the eigenvectors of covariance matrix that were used to compute principal scores.

The main limits of this approach are: even thou the outliers were excluded from analysis, the possibility of heteroskedasticity of errors is high and affects the estimators (are not BLUE anymore) and the associated tests; the analysis is limited to study the impact of a limited number of variables that characterize trade on GDP per capita growth, excluding other macroindicators that might have a higher significance influence.

As further research, this analysis can be extended by taking into consideration more years (an average of each cluster containing several years) and compare the results. Also, another extension can represent the analysis of relationship between GDP and trade components by considering the economic cycles.

\section{References}

[1] S. Mogoe and I.P. Mongale, "The Impact of International Trade on Economic Growth in South Africa: An Econometrics Analysis", Mediterranean Journal of Social Sciences, [S.1.], vol. 5, no. 14, p. 60, 2014, Available: https://www.mcser.org/journal/ index.php/mjss/article/view/3130.

[2] Y. Keho, "The impact of trade openness on economic growth: The case of Cote d'Ivoire", Cogent Economics \& Finance, Taylor \& Francis, Abingdon, vol. 5, no. 1, pp. 1-14, 2017, Available: http://dx.doi.org/10.1080/23322039.2017.1332820

[3] P. Sun and A. Heshmati, "International Trade and its Effects on Economic Growth in China”, Institute for the Study of Labor (IZA), IZA Discussion Papers, 2010. 
[4] S. Bakari, "Impact of Exports and Imports on Economic Growth in Canada: Empirical Analysis Based on Causality," MPRA Paper 75910, University Library of Munich, Germany, 2016.

[5] L. Michelis and G.K. Zestos, "Exports, Imports and GDP Growth: Causal Relations in Six European Union Countries", Journal of Economic Asymmetries, vol. 1. no. 2, 2004.

[6] H. Fitzová and L. Žídek, "Impact of Trade on Economic Growth in the Czech and Slovak Republics", Economics and Sociology, vol. 8, no 2, pp. 36-50, 2015, DOI: 10.14254/2071789X.2015/8-2/4

[7] M. Were, "Differential effects of trade on economic growth and investment: A crosscountry empirical investigation", Journal of African Trade, vol. 2, 2015, 10.1016/j.joat.2015.08.002.

[8] M., Huchet, C. Le Mouel and M. Vijil, "The relationship between trade openness and economic growth: Some new insights on the openness measurement issue", The World Economy, Wiley, vol. 41, no. 1, pp. 59-76, 2018.

[9] https://data.worldbank.org/indicator

[10] https://en.wikipedia.org/wiki/Principal_component_regression 